\title{
AN ADVANCED STATISTICAL METHOD RESEARCH ON THE EFFECT OF KNOWLEDGE USE LEVELS ON SOME SKILLS
}

\author{
Abbas Doğan", \\ Reyhan Sekerci'i, \\ Beyhan Güven', \\ Alper Güven ${ }^{1}$ \\ ${ }^{1}$ Ministry of National Education, \\ Turkey \\ ${ }^{2}$ Dr., Ministry of National Education, \\ Turkey
}

\begin{abstract}
:
The aim of this study is to examine the effect of cognitive knowledge levels of senior students studying in higher education on various variables and some performance-based skills. 265 students selected by criterion sampling method participated in the study. The validity and reliability of the data of the study were determined, collected with two separate inventories, and various advanced statistical methods were used in the analysis of the data. According to some variables, it has been determined that knowledge levels have a significant effect on some performance-based skills. The obtained data were interpreted in the light of the literature and various suggestions were made to researchers and practitioners.
\end{abstract}

Keywords: knowledge levels, skills, advanced statistical methods

\section{Introduction}

There are many studies in the literature regarding the usage level and way of educational technologies and their effects on different education levels. (Greenfield, 2009; Fenichel \& Schweingruber, 2010; Straub, 2009; Hung \& Yuen, 2010; Dabbagh \& Kitsantas, 2012; Chen \& Bryer, 2012; Lai, Khaddage \& Knezek, 2013; Vovk, Sotska, Trynus \& Muzyka, 2019). Research focusing on tools used in educational technologies has given way to how pedagogical practices can be supported. The findings support the view that early years practitioners have accessed a wider range of technologies and that these technologies are used more pedagogically appropriate than previously reported. Generally, attitudes towards educational technology are positive. However, as students need access to technology, they are surrounded by this pedagogical logic in everyday life, which increases technology learning (Jack \& Higgins, 2019).

iCorrespondence: email reyhansekerci@hotmail.com.tr 
In one study, a study examining the practices of school leaders to support the innovative use of digital technologies for teaching and learning aimed to investigate, analyze and discuss possible difficulties and possible situations for the school leader. School leaders have seen some benefits in sharing and collaboration methods in new studies and determined that digital technologies create a useful environment for their use in teaching. Difficulties are mostly technical problems, they aimed to create educational management practices that would prioritize leadership for the use of educational technologies by supporting teachers in their work (Håkansson Lindqvist, 2019). In another study, how technology has affected education in the field of digital sciences in the last decade has been examined and especially the use and adaptation of educational technology has been studied. The way to increase the use of technology in education has been determined as the attitudes, perceptions and self-efficacy of teachers, faculty and administration. Four keys are presented on how to integrate science and educational technology effectively, and specific recommendations are made regarding ways in which they can be linked (Dickson, Fidalgo, \& Cairns, 2019)

In a study that examines the goals of teachers' use of educational technologies of cultural values adopted individually, the lack of studies in developing countries and the way of using technology were discussed in the literature, and the effect of cultural values adopted individually on the level of using technology was investigated. Because technology acceptance has been recognized as an individual concern. The results determined that the way technology acceptance and use is a valid general attitude for teachers to adopt technology. Features such as usefulness, ergonomics, and usefulness were found to have an effect on attitudes towards use (Teo \& Huang, 2019). Essentially, technology was even more physically and culturally closed in the early years. However, it still has not been fully reflected in educational settings. The rationale for using technology is often 'social' rather than 'pedagogical'. Technology is often used because practitioners believe that their environment should reflect the wider world, rather than supporting a belief in the impact of technology on pedagogy (Jack, 2019).

On the other hand, with the development of technology, studies that investigate how people learn use technology to activate cognitive and affective learning. For this reason, practitioners who want to innovate in their education systems or curricula should first plan how to integrate educational technologies into this system they will create. The use of educational technologies on the basis of schools is different day by day, the fact that the educational environments are different from each other in terms of quantity and quality is also an effect, and also creates a large population and sample. In this context, the educational technology adopted may not be valid and sufficient for every environment and condition (Uncapher, 2019). As opportunities for using technology in today's technological opportunities expand, the barriers of educators in using technology may disappear. With technology-related practical and appropriate professional development opportunities starting at the application level, educators can find the opportunity to change their beliefs about technology and develop equitable learning opportunities (Siefert, Kelly, Yearta, \& Oliveira, 2019). However, in spite of all these, it is 
mentioned in some studies that some pedagogical prejudices regarding educational technologies persist and there are some anxieties and concerns that are pushed to the background. It can be said that there may be many different variables in the sub-reasons of this, culture, readiness, lack of knowledge-skills and pedagogy, etc. Many reasons such as, may be effective in this (Scardamalia \& Bereiter, 2008; Chen, Zou, Cheng \& Xie, 2020). For this reason, in this study, together with the analysis of many different variables, the answer to the following question was sought: What is the effect of the procedural knowledge levels of the teacher candidates on the use of technological equipment?

\section{Material and Methods}

This study, which aims to examine the cognitive awareness levels of pre-school teacher candidates in terms of variables such as gender, class level, educational status, and receiving pre-school education, is a screening study that tries to define the effect levels of these variables on their ability to use technological equipment.

\subsection{Universe-Sample}

The universe of the research consists of third and fourth year students of Akdeniz University Faculty of Education. The criterion, which is one of the sampling methods of the study, was determined by sampling method. Although the research was carried out with 265 teacher candidates, it was determined that 14 students did not fill the scale sufficiently and were excluded from the study.

\subsection{Demographic Characteristics of Participants}

Demographic information about the teacher candidates participating in the study is presented in Table 1.

Table 1: Demographic characteristics of the participants

\begin{tabular}{|l|l|c|c|}
\hline Specifications & 3rd Class & $\mathbf{n}$ & $\mathbf{\%}$ \\
\cline { 2 - 4 } & 4th grade & 112 & 44.6 \\
\hline \multirow{2}{*}{ Glass } & $\mathrm{F}$ & 139 & 55.4 \\
\cline { 2 - 4 } & $\mathrm{M}$ & 220 & 87.6 \\
\hline \multirow{2}{*}{$\begin{array}{l}\text { Type of high school } \\
\text { he graduated from }\end{array}$} & Normal & 31 & 12.4 \\
\cline { 2 - 4 } & Anatolian & 31 & 12.4 \\
\cline { 2 - 4 } & Anatolian Teacher & 66 & 26.3 \\
\cline { 2 - 4 } & Vocational & 56 & 22.3 \\
\hline \multirow{2}{*}{$\begin{array}{l}\text { Professional future } \\
\text { anxiety life situation }\end{array}$} & Yes & 98 & 39.0 \\
\cline { 2 - 4 } & No & 66 & 73.7 \\
\hline
\end{tabular}

When Table 1 is examined, it is also seen that $44.6 \%$ of the students in the study group are in the 3 rd grade, $55.4 \%$ are in the 4 th grade and $73.7 \%$ have future anxiety. 


\subsection{Data Collection Tool}

In the research, "Beyond Cognitive Awareness Inventory (BGAI)" and "Individual Innovativeness Scale (IIS)" were used as data collection tools. Detailed information about these vehicles is given below.

\subsubsection{Beyond Cognitive Awareness Inventory}

BCAI is a 52-item inventory developed by Schraw and Dennison (1994) to determine individuals' level of awareness beyond cognition. The original form of the inventory, which has a five-point Likert-type structure graded as "never, rarely, often, often and always", consists of 2 basic dimensions and 8 sub-factors. The first dimension, called the knowledge of cognition, reveals the individual's knowledge of cognitive processes and learning strategies. The other dimension, expressed as the regulation of cognition, reveals the knowledge of planning, organizing and evaluating the learning process. The first dimension consists of 3 sub-factors and the second dimension consists of 5 sub-factors. The results of the factor analysis performed on the original form of the inventory reveal that the total variance explained was $65 \%$ and the factor loadings varied between .31 and .70. Internal consistency coefficients also ranged from .88 to .93 for scale sub-dimensions. Turkish adaptation studies of the inventory were carried out by Akın, Abacı and Çetin in 2007. The data obtained from 607 university students were subjected to some analysis within the scope of validity and reliability studies. Findings show that the inventory is highly similar to its original form. Based on these findings, it was concluded that the inventory is a valid and reliable data collection tool that can be used in the field of educational sciences. The validity and reliability values referenced in the table below are presented in detail:

Table 2: Validity-Reliability Values of the Turkish Form of the BCAI

\begin{tabular}{|l|c|}
\hline & Value \\
\hline Linguistic Equivalence (with original form) & .93 \\
\hline Compliance Validity (with original form) & .95 \\
\hline Item Test Correlations & .95 \\
\hline Test-Retest Correlation Coefficient & .95 \\
\hline Internal Consistency Coefficient & Values between .35 and .65 \\
\hline
\end{tabular}

As can be seen from the table above, the inventory can be used safely in studies related to metacognitive awareness. The lowest score that can be obtained from the inventory consisting of 52 items is 52 and the highest score is 260 . The division of the total score obtained from the inventory to the number of items reveals the level of beyond-cognitive awareness of the individual. If this score is below 2.5, low level awareness is mentioned, if it is above, high level awareness is mentioned. 


\subsubsection{Attitude Scale towards the Use of Technological Equipment in Preschool Education}

While the version prepared for the attitude scale consisted of 37 attitude statements, then, as a result of expert opinions and statistical calculations, the final attitude scale consisting of 6 negative, 14 positive, total 20 items was created. The KMO value of the attitude scale was 0.89 , and the Barlett test was $0.00(\chi 2=1377.187 ; \mathrm{p}<0.05)$. These values show that the sample size is statistically sufficient, and the data are suitable for factor analysis. Scale As seen in the slope graph, the point where the graph curve shows a rapid decline reveals that the scale has a single factor. The total variance explained by a single factor is $40 \%$. A variance of $30 \%$ or more explained in single factor scales seems sufficient. The factor load values of the items vary between 0.441 and 0.731 .

The eigenvalue of the attitude scale was 8,188 , and the variance percentage was 41,181 . This variance rate, which is above $41 \%$ as an acceptable rate in the scales, reveals that the scale consists of a single factor. Content validity of the scale was provided by expert opinion. The reliability calculations of the attitude scale were made, and the Cronbach alpha reliability coefficient was calculated as 0.92 and Spearman Brown coefficient as 0.90 . These values reveal that the scale is highly reliable (Kol, 2012).

\subsection{Data Analysis}

The data obtained from the Attitude Scale towards the Use of Technological Equipment in Preschool Education and the Metacognitive Awareness Inventory were analyzed with the SPSS 21 package program. It was examined whether the data showed a normal distribution, and it was determined that their distribution was normal. Therefore, MANOVA, one of the multivariate statistical methods from parametric tests, was used in the analysis of the data to determine the factors affecting the attitudes of teacher candidates towards using technological equipment and their metacognitive awareness. The relationship between pre-service teachers' attitudes towards using technological equipment and their metacognitive awareness levels was examined with Pearson Moment Correlation analysis. Multiple Linear Regression Analysis was also conducted in the study to determine whether the metacognitive awareness levels of teacher candidates predicted their attitudes towards technological equipment use.

\section{Results}

In this part of the study, the factors affecting the attitudes of the teacher candidates towards using technological equipment and their metacognitive awareness levels are presented in tables and explained. In addition, analysis results related to the pre-service teachers' metacognitive awareness levels to predict their level of use of technological equipment are included. 
Table 3: Homogeneity of Variances: Levene Test

\begin{tabular}{|l|c|c|c|c|}
\hline & F & df1 & df2 & Sig. \\
\hline Tool total again & 1,128 & 15 & 234 &, $\mathbf{3 3 2}^{*}$ \\
\hline Metacognitive total & 1,851 & 15 & 234 &, 029 \\
\hline
\end{tabular}

According to Table 2, in the homogeneity test, all dependent variables "Sig." values must be greater than 0.05 . The metacognitive dependent variable Sig. Since the value is 0.029 , "With 95\% confidence, the variances for all dependent variables are homogeneous. "Can not be said. However, regarding the attitude of using technological tools, Sig. it seems significant since its value is .332 .

Table 4: Box's Test of Equality of Covariance Matrices

\begin{tabular}{|l|c|}
\hline Box's M & $\mathbf{3 9 , 8 1 4}$ \\
\hline F & 1,238 \\
\hline df1 & 30 \\
\hline df2 & $\mathbf{8 8 3 1 , 9 7 5}$ \\
\hline Sig. & $\mathbf{1 7 4}$ \\
\hline
\end{tabular}

However, considering the Box's $\mathrm{M}$ value according to Table 3, since it is greater than .05 $($ Sig. $=.174)$, the covariance distributions are equal.

$\mathrm{H} 1=$ The variance and covariance matrices of the groups are equal.

Table 5: Manova Analysis

\begin{tabular}{|l|l|c|c|c|}
\hline Effect & Value & F & Sig. \\
\hline Intercept & Wilks' Lambda &, 034 & $3273,394^{\mathrm{b}}$ &, 000 \\
\hline Gender & Wilks' Lambda &, 983 & $2,061^{\mathrm{b}}$ &, 130 \\
\hline Class & Wilks' Lambda &, 995 &, $582^{\mathrm{b}}$ &, 559 \\
\hline List & Wilks' Lambda &, 958 & $1,683^{\mathrm{b}}$ &, 123 \\
\hline Gender * Class & Wilks' Lambda &, 950 & $6,188^{\mathrm{b}}$ &, 002 \\
\hline Gender * List & Wilks' Lambda &, 963 & $1,468^{\mathrm{b}}$ &, 187 \\
\hline Class * List & Wilks' Lambda &, 955 & $1,794^{\mathrm{b}}$ &, 099 \\
\hline Gender * Class * List & Wilks' Lambda &, 964 & $1,445^{\mathrm{b}}$ &, 196 \\
\hline
\end{tabular}

When the Manova table is examined according to Table 4, considering the "Wilk's Lambda" test, Sig. It is seen that most of the values $(p<.05)$ are greater than 0.05 . Therefore, the mentioned factors do not have a statistically significant effect on dependent variables. It can be said that only gender * class interaction has a significant effect on dependent variables ("Sig." $=002<.05$ ). 
Table 6: Independent Variables Affecting the Dependent Variable

\begin{tabular}{|l|l|c|c|c|c|}
\hline Source & Dependent Variable & $\mathbf{d f}$ & Mean Square & $\mathbf{F}$ & Sig. \\
\hline \multirow{3}{*}{ Gender } & tool total again & 1 &, 841 & 4,017 &, $\mathbf{0 4 6}$ \\
\cline { 2 - 6 } & metacognitive total & 1 &, 079 &, 423 &, 516 \\
\hline \multirow{3}{*}{ Class } & tool total again & 1 &, 212 & 1,012 &, 315 \\
\cline { 2 - 6 } & metacognitive total & 1 &, 011 &, 058 &, 810 \\
\hline \multirow{2}{*}{ List } & tool total again & 3 &, 560 & 2,677 &, $\mathbf{0 4 8}$ \\
\cline { 2 - 6 } & metacognitive total & 3 &, 078 &, 418 &, 740 \\
\hline \multirow{3}{*}{ Gender * Class } & tool total again & $\mathbf{1}$ & $\mathbf{1 , 9 1 7}$ & $\mathbf{9 , 1 5 8}$ & $\mathbf{, 0 0 3}$ \\
\cline { 2 - 6 } & metacognitive total & $\mathbf{1}$ & $\mathbf{9 3 8}$ & $\mathbf{5 , 0 4 6}$ & $\mathbf{2 0 2 6}$ \\
\hline \multirow{3}{*}{ Gender * List } & tool total again & 3 &, 395 & 1,888 &, 132 \\
\cline { 2 - 6 } & metacognitive total & 3 &, 148 &, 796 &, 497 \\
\hline \multirow{2}{*}{ Class * List } & tool total again & 3 &, 614 & 2,932 & $\mathbf{, 0 3 4}$ \\
\cline { 2 - 6 } & metacognitive total & 3 &, 070 &, 377 &, 769 \\
\hline
\end{tabular}

According to Table 6, the factors affecting the dependent variables and their interactions Sig. Considering the values, gender, list type, gender * class, class * high school type have a significant effect on technological equipment attitude $(p<.05)$. Gender ${ }^{*}$ class interaction affects the metacognitive awareness level (Sig.026, $\mathrm{p}<.05$ ). The predictive status of preservice teachers' gender, grade level, type of high school they graduated from, and metacognitive awareness levels towards using technological equipment was analyzed using Multiple Linear Regression Analysis. In order to perform regression analysis, first of all, dependent and independent variables should be continuous variables and show normal distribution. When the Histogram, P-Plot and Scatter Plot are examined, it can be seen that there is a normal distribution.

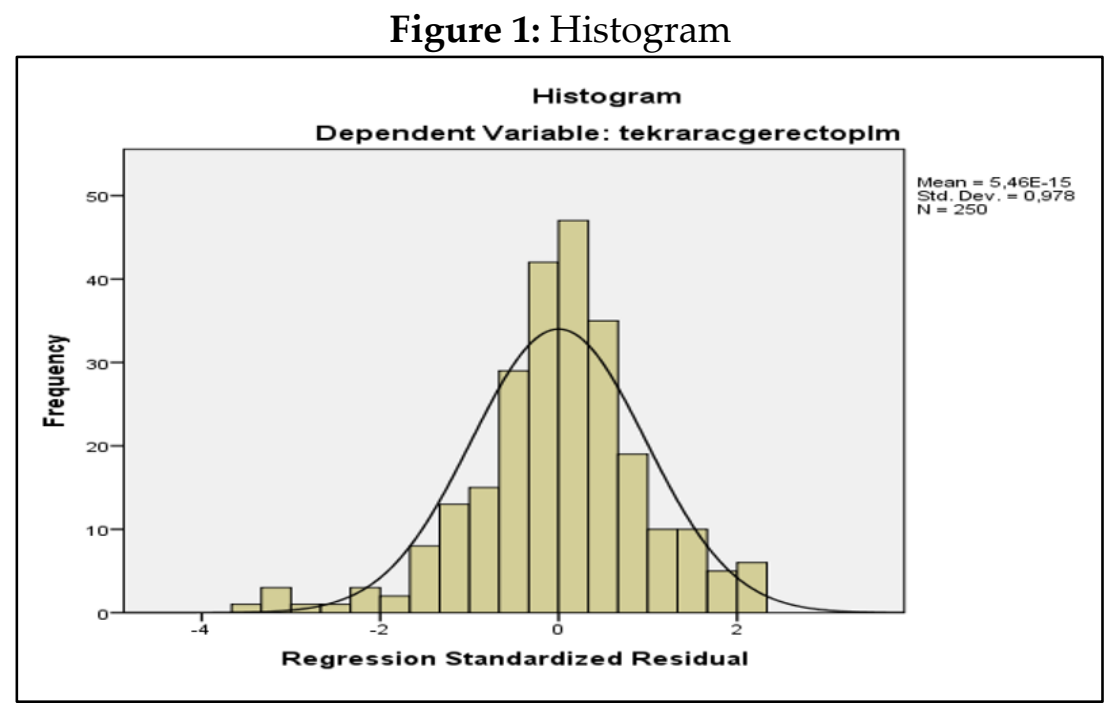

Histogram shows normal distribution. 
Figure 2: P-Plot

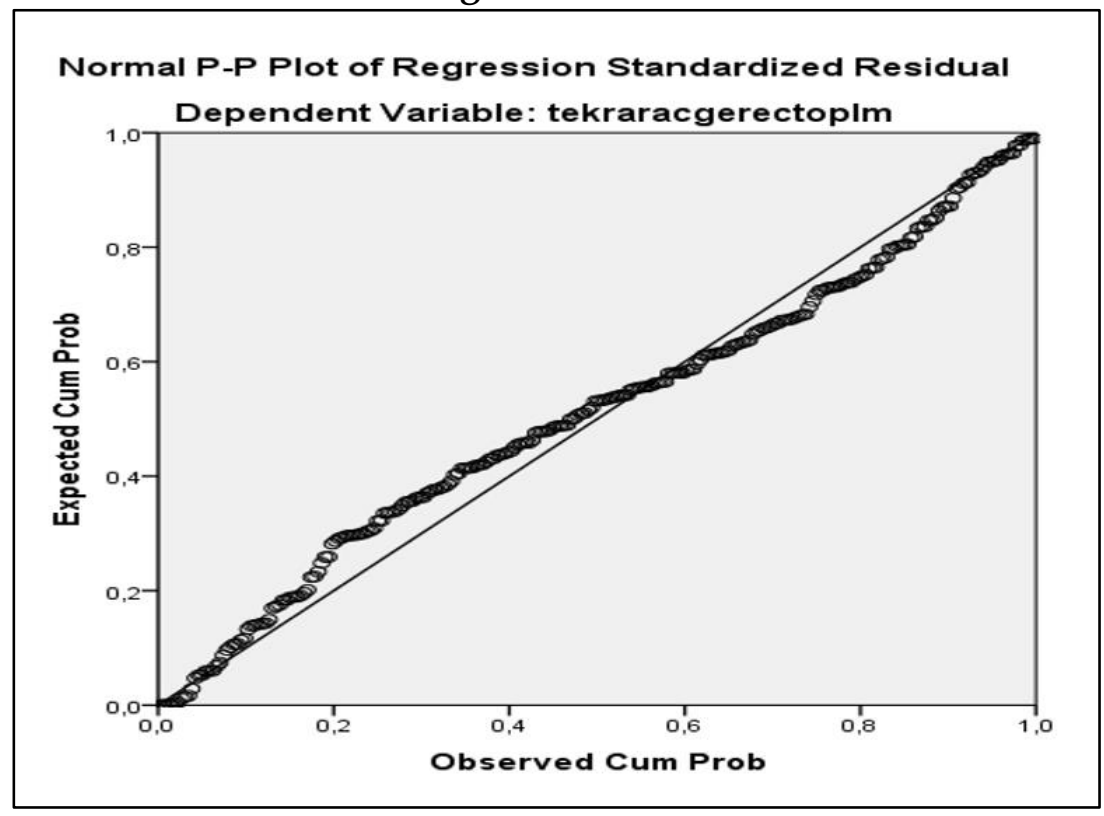

A

P-Plot shows normal distribution.

Figure 3: Scattering Diagram

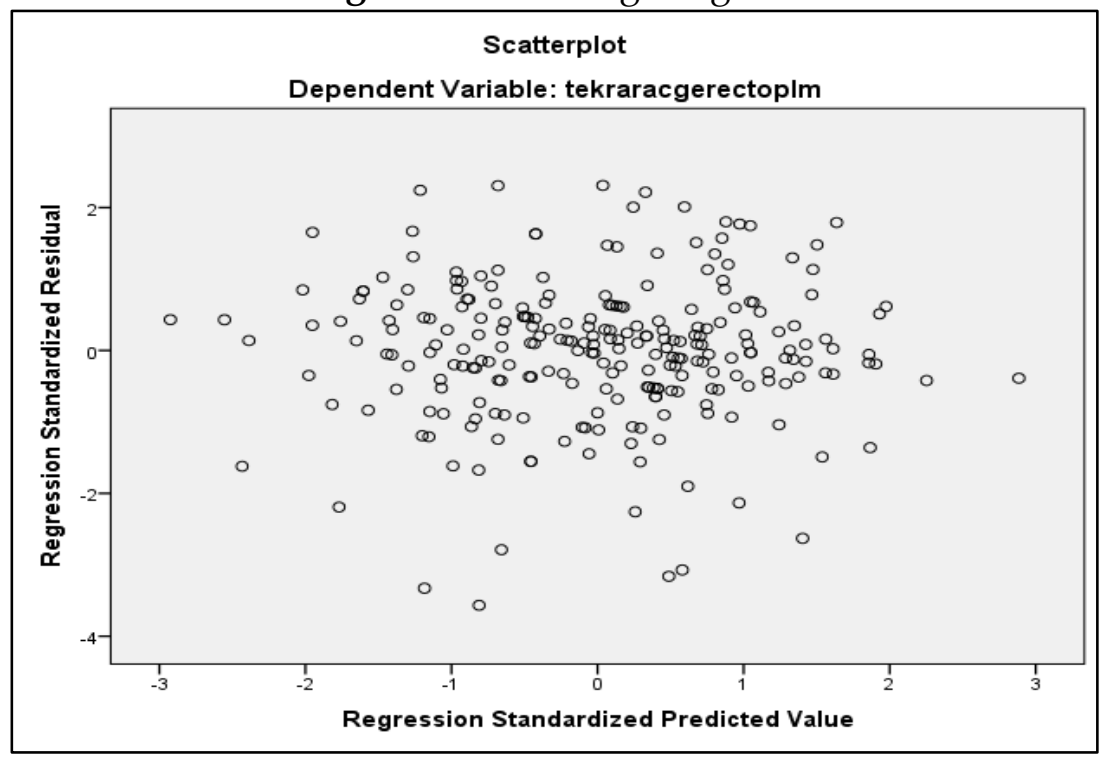

Normal distribution is seen in the scatter diagram.

When the effect of independent variables consisting of classification scales on dependent variables is examined, independent variables are converted into dummy variables (Büyüköztürk, 2011). While creating dummy variables, dummy variables are defined as one less than the number of categories of the variable (Can, 2013). For example, the chronological age of children variable was coded as (1) $\leq 60-64$ months, (2) 65-69 months, and (3) $\geq 70$ months in the data set. Since the chronological age variable consists of three subcategories, two dummy variables are defined. The category (1) in the variable was evaluated as dummy and re-coded as " 0 " for the two dummy variables created. 
Category (2) for the chronological age 1 variable is " 1 ", the other category is " 0 ", for the chronological age 2 variable, category (3) is "1" and the other category is "0" and used in the analysis. Similarly, two dummy variables are defined for the variables of family income and number of siblings.

One of the assumptions of multiple linear regression analysis is that there is no multicollinearity between variables. Multicollinearity is the absence of a high level of correlation between variables, and it is determined by the correlations between independent variables (Büyüköztürk, 2011). Correlations between dependent and independent variables were examined with the Pearson Product Moment Correlation Coefficient and the results are presented in Table 6.

Table 7: Correlation Table Between Independent Variables

\begin{tabular}{|c|c|c|c|c|c|c|c|c|c|c|c|c|}
\hline Variable & 1 & 2 & 3 & 4 & 5 & 6 & 7 & 8 & 9 & 10 & 11 & 12 \\
\hline $\begin{array}{l}\text { 1. Using } \\
\text { technological } \\
\text { tools }\end{array}$ & - & .10 & .21 & .15 & .15 & .17 & .17 & .17 & .11 & .15 & -.11 & .16 \\
\hline $\begin{array}{l}\text { 2. Factor } 1 \\
\text { (Explanatory } \\
\text { Information) }\end{array}$ & & - & .50 & .59 & .56 & .58 & .45 & .45 & .61 & .24 & -.08 & .06 \\
\hline $\begin{array}{l}\text { 3.Factor } 2 \\
\text { (Procedural } \\
\text { Information) }\end{array}$ & & & - & .58 & .61 & .65 & .51 & .44 & .60 & .14 & -.03 & .17 \\
\hline $\begin{array}{l}\text { 4. Factor } 3 \\
\text { (Situational } \\
\text { Information) }\end{array}$ & & & & - & .58 & .59 & .53 & .52 & .62 & .16 & -.01 & .05 \\
\hline $\begin{array}{l}\text { 5. Factor } 4 \\
\text { (Planning) }\end{array}$ & & & & & - & .74 & .61 & .57 & .67 & .19 & -.22 & .10 \\
\hline $\begin{array}{l}\text { 6. Factor } 5 \\
\text { (Monitoring) }\end{array}$ & & & & & & - & .66 & .58 & .67 & .19 & -.16 & .13 \\
\hline $\begin{array}{l}\text { 7. Factor } 6 \\
\text { (Evaluation) }\end{array}$ & & & & & & & - & .50 & .55 & .26 & -.10 & .15 \\
\hline $\begin{array}{l}\text { 8. Factor } 7 \\
\text { (Debugging) }\end{array}$ & & & & & & & & - & .59 & .20 & -.14 & .10 \\
\hline $\begin{array}{l}\text { 9. Factor } 8 \\
\text { (Knowledge } \\
\text { Management) }\end{array}$ & & & & & & & & & - & .18 & -.16 & .05 \\
\hline Grade 10 & & & & & & & & & & - & .01 & 17 \\
\hline 11. Gender & & & & & & & & & & & - & .05 \\
\hline $\begin{array}{l}\text { 12. Type of } \\
\text { high school }\end{array}$ & & & & & & & & & & & & - \\
\hline
\end{tabular}

When Table 7 is examined, it is seen that the statistically significant relationship between variables is .74. Since correlation values above .80 show multiple connections, it can be said that there is no multiple connection problem according to Pearson moments product correlation coefficients (Büyüköztürk, 2011). One of the assumptions in regression analysis is that there is no autocorrelation (independence of error terms). Durbin Watson statistics are used to determine autocorrelation and the resulting values are expected to 
be between 1.5-2.5 (Kalaycl, 2016). It was determined in the analysis that the Durbin Watson value calculated was 1.848 and was between the expected values.

Table 8: Regression Analysis

\begin{tabular}{|c|c|c|c|c|c|c|c|c|c|}
\hline \multirow{2}{*}{ Model } & \multirow{2}{*}{$\mathbf{R}$} & \multirow{2}{*}{$\begin{array}{c}\mathbf{R} \\
\text { Square }\end{array}$} & \multirow{2}{*}{$\begin{array}{c}\text { Adjusted } \mathbf{R} \\
\text { Square }\end{array}$} & $\begin{array}{c}\text { R Square } \\
\text { Change }\end{array}$ & $\begin{array}{c}\mathbf{F} \\
\text { Change }\end{array}$ & $\mathbf{d f 1}$ & $\mathbf{d f 2}$ & $\begin{array}{c}\text { Sig. F } \\
\text { Durbin- } \\
\text { Watson }\end{array}$ \\
\hline 1 &, $253^{\mathrm{a}}$ &, 064 &, 033 &, 064 & 2,063 & 8 & 241 &, 040 & \multirow{2}{*}{$\mathbf{1 , 8 4 8}$} \\
\hline 2 &, $315^{\mathrm{b}}$ &, 099 &, 058 &, 035 & 3,095 & 3 & 238 &, 028 & \\
\hline
\end{tabular}

According to Table 8 , the $\mathrm{R}^{2}$ value was used in the regression analysis to determine what percentage of the total change in pre-service teachers' metacognitive awareness levels, gender, grade levels and the attitudes towards using technological equipment of the high school they graduated from was due to independent predicted variables (Bayram, 2017). In addition, the standardized regression coefficient $(\beta)$ was taken into account to determine the relative importance order of the predictive variables on the predicted variable (Punch \& Oancea, 2014).

Table 9: Analysis Results on the Prediction of Technological Equipment Use Attitude

\begin{tabular}{|l|c|c|c|c|c|c|c|}
\hline Variable & $\mathbf{B}$ & Standard Error & $\mathbf{B}$ & $\mathbf{t}$ & $\mathbf{p}$ & $\mathbf{F}$ & $\mathbf{R}^{\mathbf{2}}$ \\
\hline Constant & 3.32 & .29 & & 11.18 & .00 & & \\
\hline $\begin{array}{l}\text { F1 } \\
\text { (Explanatory Information) }\end{array}$ & -.04 & .08 & -.05 & -.59 & .55 & \\
\hline $\begin{array}{l}\text { F2 } \\
\text { (Procedure Information) }\end{array}$ & .14 & .06 & .18 & 2.05 & .04 & \\
\hline $\begin{array}{l}\text { F3 } \\
\text { (Situational Information) }\end{array}$ & .04 & .07 & .05 & .60 & .54 \\
\hline $\begin{array}{l}\text { F4 (Planning) } \\
\text { (Monitoring) }\end{array}$ & -.03 & .08 & -.04 & -.40 & .68 & \\
\hline $\begin{array}{l}\text { F5 } \\
\text { (M6 } \\
\text { (Rating) }\end{array}$ & .02 & .09 & .02 & .22 & .82 & \multirow{2}{*}{2.384} & \multirow{2}{*}{.09} \\
\hline $\begin{array}{l}\text { F7 } \\
\text { (Debug) }\end{array}$ & .02 & .06 & .04 & .46 & .64 & \\
\hline $\begin{array}{l}\text { F8 } \\
\text { (Knowledge Management) }\end{array}$ & .07 &. .10 & .06 & .09 & 1.13 & .26 & \\
\hline Class & .10 & .06 & .11 & 1.71 & .08 \\
\hline Gender & -.16 & .09 & -.11 & 1.71 & .08 \\
\hline High school type & 04 & .02 & .10 & 1.60 & .11 & \\
\hline
\end{tabular}

As the $\mathrm{F}$ value obtained in the regression analysis examining the predictive status of the teacher candidates' gender, class level, type of high school they graduated from and metacognitive awareness levels towards using technological equipment, it was concluded that the regression model was appropriate $(F(8-241)=2.384 p<.05)$. As a result of the regression analysis, it is seen that the specified variables are low and significantly 
related to the attitude towards using technological equipment $\left(R=0.31, R^{2}=0.09 p<.05\right)$. Based on this, it can be said that the metacognitive awareness levels of prospective teachers explain $9 \%$ of the variance in their attitudes towards using technological equipment. When the results of the $t$ test regarding the standardized regression coefficient $(\beta)$ and the significance of the regression coefficients are examined, it is seen that the only variable that predicts the attitudes of pre-service teachers towards using technological equipment is Factor 2, that is, Procedural Knowledge.

\subsection{Regression Equation}

$\mathrm{Y}($ Technological Tool Usage $)=3.22+(0.02 *$ Explanatory Information $)+(0.14 *$ Procedural Information $)+(0.01 *$ Situational Information $)+(0.01 *$ Planning $)+(0.02 *$ Monitoring $)+(0.05 *$ Evaluation $)+(0.1 *$ Error Explanation $)+(0.10 *$ Managing Knowledge. Table 10. Correlation Between Estimated Variables.

\begin{tabular}{|c|c|c|c|c|c|c|c|}
\hline & & B & Beta & $t$ & Sig. & Tolerance & VIF \\
\hline \multirow[t]{9}{*}{1} & (Constant) & 3,227 & & 12,547 & , 000 & & \\
\hline & factor1 &,- 029 &,- 030 &,- 350 & ,727 & ,517 & 1,934 \\
\hline & 2 & , 141 & , 185 & 2,070 & ,039 & 485 & 2,062 \\
\hline & 3 & ,015 & ,018 & 197 & 844 & ,461 & 2,171 \\
\hline & 4 &,- 009 &,- 011 &,- 109 & ,914 & ,357 & 2,802 \\
\hline & 5 & ,027 & ,031 & ,273 & ,785 & ,306 & 3,266 \\
\hline & 6 & ,054 & ,075 & ,858 & ,392 & ,504 & 1,984 \\
\hline & 7 & ,096 & ,117 & 1,400 & , 163 & ,552 & 1,813 \\
\hline & 8 &,- 104 &,- 115 & $-1,135$ & ,258 & 377 & 2,650 \\
\hline \multirow[t]{12}{*}{2} & (Constant) & 3,324 & & 11,184 & ,000 & & \\
\hline & 1 &,- 048 &,- 051 &,- 593 & ,554 & ,506 & 1,977 \\
\hline & 2 & , 141 & , 184 & 2,052 & ,041 & ,468 & 2,136 \\
\hline & 3 & ,047 & ,055 & 602 & ,548 & , 450 & 2,224 \\
\hline & 4 &,- 035 &,- 043 &,- 406 & 685 & ,345 & 2,902 \\
\hline & 5 & ,022 & ,025 & ,228 & 820 & ,305 & 3,278 \\
\hline & 6 & , 029 & ,041 & ,461 & ,646 & ,489 & 2,046 \\
\hline & 7 & ,077 & ,094 & 1,130 & ,260 & ,546 & 1,830 \\
\hline & 8 &,- 100 &,- 111 & $-1,102$ & ,271 & ,372 & 2,690 \\
\hline & class & ,109 & ,112 & 1,716 & ,088 & ,881 & 1,135 \\
\hline & gender &,- 163 &,- 111 & $-1,714$ & ,088 & 899 & 1,113 \\
\hline & list & ,047 & 103 & 1,604 & 110 & ,925 & 1,081 \\
\hline
\end{tabular}

According to Table 10, it is seen that VIF values are below 10 and tolerance statistics are above 0.2. In other words, there is no perfect linear relationship between predictive variables. So, there is no high correlation between variables. Factor 2 (procedural information) was found to be significant because it was less than .05 in terms of values.

As a result:

"H1: Procedural knowledge has a positive effect on the use of technological equipment." can be called. 


\section{Conclusion, Discussion and Recommendations}

There is a general belief that our education systems face different challenges while trying to meet the needs of society in a changing and increasingly technological age. On the other hand, there is an uncertainty regarding the benefits of technology and the differences that it causes (Dooley, 1999). However, these developing technological changes can also offer a unique perspective to practitioners and theorists in the preparation of education and training environments (Uncapher, 2019). According to the results of our study, according to the effect of procedural knowledge on the use of technological tools, preparing guidelines and instructions for the use of tools and equipment in order to ensure the practicality of technological tools and equipment in teacher education or in teachers' professional life, simple and clear explanation of the steps will increase the use of technological tools. Because practitioners of education or training programs using electronic technology may ask many questions about a project while they are still in the early stages of development. For example: Is the presentation of the program too simple or too complex for the target audience? How we can make it easier to use Flagg, 2013).

In this respect, one of the main measures to increase and develop the technological equipment use skills of teacher candidates and teachers is to remove the obstacles to use and experimentation. For example, by examining a series of development courses offered through e-learning methods, educational technology fundamentals were examined and the following data were presented: i) characteristics of the participants; ii) main factors enabling them to participate; iii) evaluation of lessons. The findings show that e-learning is a new reality that needs to be studied at many levels and that various factors are taken into account (Gouvias, Vitsilakis \& Kostas, 2019). In addition, educational technologies likely to be used are still being researched and developed (Alario-Hoyos, PérezSanagustín, Delgado-Kloos, Muñoz-Organero \& Rodríguez-de-las-Heras, 2013; Clark \& Estes, 1999; Spector, 2013). In this study, it was seen in the interviews with the participant teacher candidates that the pre-service teachers were afraid to use technological tools and had concerns about making mistakes or damaging them. In this regard, especially for academics and teachers, educational administrators should encourage current teacher candidates and teachers, and teachers should be encouraged in this regard. In addition, it will be beneficial to provide live one-to-one support with e-learning as well as procedural information during the application. For example, a pre-service teacher stated his thoughts on the subject while applying the measurement tools:

"Although I can use social media and technological devices very well, I hesitate to benefit from educational technologies. Because I'm afraid of damaging it or making it useless. For this reason, I prefer not to use it at all. For example, I am worried even when using the microscope in the laboratory, I do not know how to get help from whom. I prefer to show the subject and feature that I will tell on the internet instead of it in a virtual environment. This is easier. As far as I observed in practice school, even children are braver than us. They 
are microscopes etc. more eager and more eager to try things out. "(pre-school teacher candidate)

Based on this, it can be said that pedagogical prejudices regarding educational technologies continue and there are some concerns and concerns that are pushed to the background (Scardamalia \& Bereiter, 2008; Chen, Zou, Cheng \&Xie, 2020). On the other hand, while designing the use of educational technologies in education and training environments, goals, content, and the size of the application area should be considered quantitatively and qualitatively (Uncapher, 2019). Based on all these, revising the training for prospective teachers and teachers, especially in basic education, which is relatively small in terms of educational technologies but universally in large groups and in basic education institutions that are suitable for the characteristics of students, making the tools used in the field of educational technologies ergonomic and leaving standard education patterns It is extremely important and necessary. In addition, in order to increase the flexibility of learning in higher education, the appropriateness of using educational technologies should be examined, the application of interactive education technologies in different countries should be investigated and different new and original models should be used (Breines \& Gallagher, 2020; Cabaleiro-Cerviño \& Vera, 2020; Mosenkis, Lukianyk, Strokal, Ponomarova \& Mykhailiuk, 2020; Nawaz, Awan, \& Ahmad, 2011; Olofsson \& Lindberg, 2012; Roberts, 2008; Ugur, 2020; Vaganova, 2019; Ziguras, 2001).

\section{Conflict of Interest Statement}

The authors declare no conflicts of interests.

\section{About the Authors}

Abbas Dogan works as a Branch Manager at the Ministry of National Education and holds a PhD in Educational Administration and Supervision.

Reyhan Sekerci (PhD) works as a Class Teacher at Konyaaltı Primary School. Her research publications and research interests: teacher leadership, mobbing, comparative education, classroom management, informal education, adult education, adult learning lifelong learning.

Beyhan Güven works as educational administrator, holds master's degrees in the field of Educational Administration and Supervision; also, works in the Ministry of National Education.

Alper Güven works as educational administrator who hold master's degrees in the field of Educational Administration and Supervision; also, works in the Ministry of National Education. 


\section{References}

Akin, A., Abaci, R., \& Cetin, B. (2007). The validity and reliability of the Turkish version of the metacognitive awareness inventory. Educational Sciences: Theory \& Practice, 7 (2), 671.

Alario-Hoyos, C., Pérez-Sanagustín, M., Delgado-Kloos, C., Muñoz-Organero, M., \& Rodríguez-de-las-Heras, A. (2013, September). Analysing the impact of built-in and external social tools in a MOOC on educational technologies. In European Conference on Technology Enhanced Learning (pp. 5-18). Springer, Berlin, Heidelberg.

Balc1, A. (2004). Research in social sciences. Ankara: Pegem Publishing.

Bayram, N. (2017). Data analysis with SPSS in social sciences. Ezgi Bookstore.

Breines, M. R., \& Gallagher, M. (2020). A return to Teacherbot: rethinking the development of educational technology at the University of Edinburgh. Teaching in Higher Education, 1-15.

Büyüköztürk, Ş. (2011). Data analysis handbook in social sciences. Pegem Publishing House, Ankara.

Cabaleiro-Cerviño, G., \& Vera, C. (2020). The Impact of Educational Technologies in Higher Education. GIST-Education and Learning Research Journal, 20, 155-169.

Can, A. (2013). Qualitative Data Analysis. Ankara: Pegem Publishing

Chen, B., \& Bryer, T. (2012). Investigating instructional strategies for using social media in formal and informal learning. The International Review of Research in Open and Distributed Learning, 13(1), 87-104.

Chen, X., Zou, D., Cheng, G., \&Xie, H. (2020). Detecting latent topics and trends in educational technologies over four decades using structural topic modeling: A retrospective of all volumes of computer \& education. Computers \& Education, 103855.

Clark, R. E., \& Estes, F. (1999). The development of authentic educational technologies. Educational Technology, 5-16.

Dabbagh, N., \& Kitsantas, A. (2012). Personal Learning Environments, social media, and self-regulated learning: A natural formula for connecting formal and informal learning. The Internet and higher education, 15(1), 3-8.

Dickson, M., Fidalgo, P., \& Cairns, D. (2019). The 'S' and 'T' In STEM: Integrating science and technology in education in the UAE. In Education in the United Arab Emirates (pp. 95-111). Springer, Singapore.

Dooley, K. E. (1999). Towards a holistic model for the diffusion of educational technologies: An integrative review of educational innovation studies. Journal of Educational Technology \& Society, 2(4), 35-45.

Fenichel, M., \& Schweingruber, H. A. (2010). Surrounded by science: Learning science in informal environments. National Academies Press.

Flagg, B. N. (2013). Formative evaluation for educational technologies. Routledge. 
Greenfield, P. M. (2009). Technology and informal education: What is taught, what is learned. Science, 323(5910), 69-71.

Gouvias, D., Vitsilakis, C., \& Kostas, A. (2019). E-Moving forward-emerging issues regarding e-learning in non-formal education in Greece. European Journal of Open Education and E-learning Studies.

Håkansson Lindqvist, M. (2019). School leaders' practices for innovative use of digital technologies in schools. British Journal of Educational Technology, 50 (3), 12261240 .

Hung, H. T., \& Yuen, S. C. Y. (2010). Educational use of social networking technology in higher education. Teaching in higher education, 15(6), 703-714.

Kalaycı, Ş. (2016). SPSS Applied multivariate statistics techniques. Ankara: Pegem Publishing.

Karasar, N. (2009). Scientific research method. Ankara: Nobel Yayın Dağıtım.

Kol, S. (2012). Developing an attitude scale towards the use of technological equipment in pre-school education. Kastamonu Education Journal, 20 (2), 543-554.

Kuş, E. (2007). Quantitative-qualitative research techniques. 2nd Edition. Ankara: Anı Publishing.

Lai, K. W., Khaddage, F., \& Knezek, G. (2013). Blending student technology experiences in formal and informal learning. Journal of Computer Assisted Learning, 29(5), 414-425.

Jack, C. (2019). Enhancing the use of Educational Technologies in the Early Years (Doctoral dissertation, Durham University).

Jack, C., \& Higgins, S. (2019). Embedding educational technologies in early years education. Research in learning technology, 27.

Mason J. (2002). Qualitative researching. 2nd. Ed. London: Sage Publications Ltd.

Morse, J. M., Barrett, M., Mayan, M., Olson, K. And Spiers, J. (2002). Verification strategies for establishing reliability and validity in qualitative research, International Journal of Qualitative Methods, 1(2), 13-22.

Mosenkis, I. L., Lukianyk, L. V., Strokal, O. M., Ponomarova, V. A., \& Mykhailiuk, H. V. (2020). Application of cloud educational technologies for teacher competence development. International Journal of Learning, Teaching and Educational Research, 19(5), 289-303.

Nawaz, A., Awan, Z., \& Ahmad, B. (2011). Integrating educational technologies in higher education of the developing countries. Journal of Education and Practice, 2(2), 113.

Newman, M. (2019). Book review: open and distance non-formal education in developing countries by Colin Latchem. Journal of Learning for Development-JL4D, 6(1).

Nygren, H., Nissinen, K., Hämäläinen, R., \& De Wever, B. (2019). Lifelong learning: Formal, non-formal and informal learning in the context of the use of problemsolving skills in technology rich environments. British Journal of Educational Technology. 
Patton, M., Q. (1990). Qualitative evaluation and research. 2nd.Ed. California, USA: SagePub. Inc.

Punch, K. F., \& Oancea, A. (2014). Introduction to research methods in education. Sage.

Olofsson, A. D., \& Lindberg, J. O. (2012). Informed design of educational technologies in higher education: Enhanced learning and teaching. Hershey ${ }^{\wedge}$ ePA PA: Information Science Reference.

Roberts, C. (2008). Implementing Educational Technology in Higher Education: A Strategic Approach. Journal of Educators Online, 5(1), n1.

Rubin, H. \& Rubin, I. (1995). Qualitative interviewing: The art of hearing data. Thousand Oaks, CA: Sage.

Scardamalia, M., \& Bereiter, C. (2008). Pedagogical biases in educational technologies. Educational Technology, 3-11.

Schraw, G., \& Dennison, R. S. (1994). Assessing metacognitive awareness. Contemporary educational psychology, 19(4), 460-475.

Siefert, B., Kelly, K., Yearta, L., \& Oliveira, T. (2019). Teacher perceptions and use of technology across content areas with linguistically diverse middle school students. Journal of Digital Learning in Teacher Education, 35(2), 107-121.

Spector, J. M. (2013). Emerging educational technologies and research directions. Journal of Educational Technology \& Society, 16(2), 21-30.

Straub, E. T. (2009). Understanding technology adoption: Theory and future directions for informal learning. Review of Educational Research, 79(2), 625-649.

Teo, T., \& Huang, F. (2019). Investigating the influence of individually espoused cultural values on teachers' intentions to use educational technologies in Chinese universities. Interactive Learning Environments, 27(5-6), 813-829.

Turgut, Y. (2009). Data recording, analysis, interpretation: quantitative and qualitative. Tanrı̈ğen, A., (Ed.), Scientific research methods. (p. 193-247). Ankara: Anı Publishing.

Ugur, N. G. (2020). Digitalization in higher education: A qualitative approach. International Journal of Technology in Education and Science, 4(1), 18-25.

Uncapher, M. R. (2019). Design considerations for conducting large-scale learning research using innovative technologies in schools. Mind, Brain, and Education, 13(1), 62-69.

Vaganova, O. I. (2019). Organization of practical classes in a higher educational institution using modern educational technologies. Amazonia Investiga, 8(23), 8186.

Vovk, M. P., Sotska, H. I., Trynus, O. V., \& Muzyka, O. J. (2019). Assessment of instructors' technology competency to be used in the settings of formal and non-formal education. International Journal of Higher Education, 8(5), 29-44.

Ziguras, C. (2001). Educational technology in transnational higher education in South East Asia: the cultural politics of flexible learning. Journal of Educational Technology \& Society, 4(4), 8-18. 
Creative Commons licensing terms

Authors will retain the copyright of their published articles agreeing that a Creative Commons Attribution 4.0 International License (CC BY 4.0) terms will be applied to their work. Under the terms of this license, no permission is required from the author(s) or publisher for members of the community to copy, distribute, transmit or adapt the article content, providing a proper, prominent and unambiguous attribution to the authors in a manner that makes clear that the materials are being reused under permission of a Creative Commons License. Views, opinions and conclusions expressed in this research article are views, opinions and conclusions of the author(s). Open Access Publishing Group and European Journal of Alternative Education Studies shall not be responsible or answerable for any loss, damage or liability caused in relation to/arising out of conflict of interests, copyright violations and inappropriate or inaccurate use of any kind content related or integrated on the research work. All the published works are meeting the Open Access Publishing requirements and can be freely accessed, shared, modified, distributed and used in educational, commercial and non-commercial purposes under a Creative Commons Attribution 4.0 International License (CC BY 4.0). 